\title{
Factors influencing consumers' attitude and repurchase intention towards Online Food Delivery (OFD) services in Indonesia
}

\author{
M.R. Hakim \& N. Sobari \\ Faculty of Economics and Business Universitas Indonesia, DKI Jakarta, Indonesia
}

\begin{abstract}
Online Food Delivery (OFD) services transaction in Indonesia has been growing rapidly and become more popular compared to the pre-COVID-19 pandemic situation. Considering this issue, this study aims to empirically investigate consumers' attitude and repurchase intention towards OFD services in Indonesia by employing the technology acceptance model (TAM), a theory of planned behavior (TPB), and partial adoption of the extended information technology continuance model (ITCM). The study examined the structural relationship between hedonic motivation, price saving orientation, time saving orientation, prior online purchase experience, information fit-to-task, visual appeal, convenience motivation, postusage usefulness, attitude towards OFD services, and repurchase intention towards OFD services. There were 207 questionnaires collected to test the research model using structural equation modeling (SEM). It was found that eight of the sixteen proposed hypotheses were accepted. In addition, this study discusses its practical implication, limitation, and suggestion.
\end{abstract}

\section{INTRODUCTION}

Online Food Delivery (OFD) services transaction in Indonesia has increased significantly during the COVID-19 pandemic (Yuswohady, 2020). At such times, consumers are avoiding eating at a restaurant and prefer to order food and beverage (F\&B) through OFD services. It shows that the consumers shift from ordering for indulgence to utility function and from occasional to repetitive activity. In this case, their motivations to order F\&B using OFD services are invaluable. Several previous studies found several factors influencing consumers' attitude and repurchase intention of online shopping and OFD services, including hedonic motivation (HM), price saving orientation (PSO), time saving orientation (TSO), prior online purchase experience (POPE), information fit-totask (IFT), visual appeal (VA), convenience motivation (CM), post-usage usefulness (PU), attitude (AOFDS), and repurchase intention towards OFD services (RIOFDS). Therefore, this study aims to examine the structural relationship between

HM, PSO, TSO, POPE, IFT, VA, CM, PU, AOFDS, and RIOFDS towards OFD services in Indonesia. It is expected that results could provide valuable inputs for OFD companies to develop strategies that could increase consumers repurchase intention towards OFD services.

\section{LITERATURE REVIEW}

This study is based on TAM (Davis, 1989), TPB (Ajzen, 1991), and partial adoption of the extended ITCM (Bhattacherjee et al., 2008). Hedonism is essential in online shopping as it links to shopping enjoyment (Ingham et al., 2015). It reveals that consumers' hedonic motivation positively affects convenience motivation and post-usage usefulness on OFD services (Yeo et al., 2017). In addition, price wars among online sellers provide convenience for consumers to compare prices (Quelch \& Klein, 1996). A study revealed that consumers consider online purchase as a valuable transaction as 
they can compare offers from various retail before making purchase (Audrain-Pontevia et al., 2013) and beneficial to buyers who get products at lower costs (Chiu et al., 2014). Besides, that time saving provides convenience preferred by consumers. Thus, price saving orientation and time saving orientation positively affect convenience motivation and post-usage usefulness of OFD services (Yeo et al., 2017). Consumer online shopping experience is a determinant factor motivating the convenience of consumers in using service (Hernández-Ortega et al., 2008). Hence, consumers will gain accumulated knowledge from their shopping experience influencing their future decisions and usefulness perception (Lord \& Maher, 1990).

Loiacono et al. (2017) explained that information fit-to-task simplifies website displays to show appropriate information for users to do a task. In this case, consumers will consider a website to be useful for shopping if it has complete information assisting them do tasks. In addition, visual appeal is an element seen on a website, which according to Tractinsky et al (2000) influences user perception on website's usefulness. In this case, Xiang et al. (2016) found that information fit-to-task and visual appeal positively influenced perceived usefulness. Davis (1989) stated that perceived ease of use refers to the extent to which a person believes the system will minimalize their effort in completing something. Perceived usefulness can be defined as the extent to which a person believes that using a system will improve the performance of an activity. Har \& Eze (2011) stated that perceived ease of use and perceived usefulness positively affect repurchase intention. Yeo et al. (2017) supersedes perceived ease of use with convenience motivation and perceived usefulness with post-usage usefulness. Moreover, convenience motivation positively influenced post-usage usefulness, attitude, and behavioral intention on OFD services. On the other hand, post-usage usefulness positively influenced attitude and behavioral intention on OFD services. Limayem et al. (2006) found that attitude on online shopping is the factor determining the shopping intention.

\section{RESEARCH METHOD}

To test the proposed model (Figure 1), this study employed a quantitative and purposive sampling technique by involving 207 Go-Food or GrabFood users using the service on 9 March9 May 2020 as its sample. We used items from Yeo et al. (2017) to measure HM, PSO, TSO, POPE, CM, PU, AOFDS, and RIOFDS, Xiang et al. (2016) and Loiacono et al. (2007) to measure IFT, and Xiang et al. (2016) to measure VA. Moreover, a five-point Likert scale was adopted. The pre-test was distributed online to 30 respondents and fulfill validity and reliability requirement. Moreover, the main test used Structural Equation Modeling (SEM) to examine the relationship between variables, which consists of measurement and structural model.

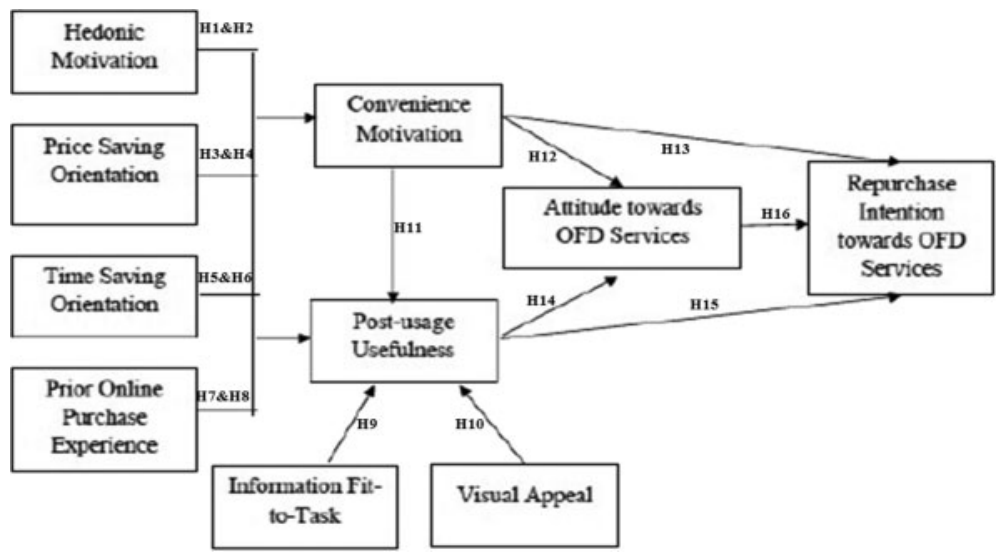

Figure 1. Research model. 


\section{RESULTS AND DISCUSSION}

The respondents consisted of $76.33 \%$ female and $23.67 \%$ male. Most of them were $21-30$ years old, had a monthly income between Rp 5,000,001-Rp10,000,000, private employees, have been using OFD services for more than two years, and recently used OFD services less than a week ago. It was found that after the COVID-19 pandemic ends, $28.50 \%$ respondents would increase their frequency of purchasing F\&B through OFD services, $29.47 \%$ would decrease it, and the rest would remain the same. Based on confirmatory factor analysis, all indicators and variables were valid and reliable ( $\mathrm{SLF} \geq 0.50 ; \mathrm{t}$-value $\geq 1.645 ; \mathrm{CR} \geq 0.70 ; \mathrm{VE} \geq 0.50$ ). The research model has ten good fit indexes (RMSEA, NNFI, NFI, RFI, IFI, CFI, normed chi-square, ECVI, AIC, and CAIC). In this study, only eight of sixteen hypotheses have t-value > 1.645 (H3, H5-H8, H11, H14-H15), which were accepted (Table 1). It was also found that: (1) PSO, TSO, and POPE had a significant positive influence on CM; (2) TSO, POPE, and CM had a significant positive influence on PU; and (3) PU had a significant positive influence on AOFDS and RIOFDS. These findings empirically support previous studies.

Table 1. Path diagram results for the structural model

\begin{tabular}{|c|c|c|c|c|c|c|c|}
\hline $\mathrm{H}$ & Path & T-value & Evaluation & $\mathrm{H}$ & Path & T-value & Evaluation \\
\hline 1 & $\mathrm{HM}->\mathrm{CM}$ & 1.04 & Not Supported & 9 & IFT- $>$ PU & 0.90 & Not Supported \\
\hline 2 & HM-> PU & 0.57 & Not Supported & 10 & $\mathrm{VA}->\mathrm{PU}$ & 0.47 & Not Supported \\
\hline 3 & PSO-> CM & 2.43 & Supported & 11 & $\mathrm{CM}->\mathrm{PU}$ & 1.99 & Supported \\
\hline 4 & PSO-> PU & 0.76 & Not Supported & 12 & $\mathrm{CM}->$ AOFDS & 0.18 & Not Supported \\
\hline 5 & TSO- $>$ CM & 2.92 & Supported & 13 & CM-> RIOFDS & 0.93 & Not Supported \\
\hline 6 & TSO-> PU & 6.03 & Supported & 14 & PU-> AOFDS & 5.46 & Supported \\
\hline 7 & POPE-> CM & 2.74 & Supported & 15 & PU-> RIOFDS & 5.84 & Supported \\
\hline 8 & POPE-> PU & 2.54 & Supported & 16 & AOFDS-> RIOFDS & -0.50 & Not Supported \\
\hline
\end{tabular}

Source: Result of statistical data using LISREL

The OFD services were often used by consumers as a routine activity as they perceive the service convenient. In this case, consumers perceived that OFD services could give them benefits while fulfilling their daily needs (utility function) and not merely pleasure. According to Yuswohady (2020), consumers use OFD services to meet their utility and not for satisfying their indulgence. Therefore, $\mathrm{H} 1$ and $\mathrm{H} 2$ are rejected. The charge prices of Go-Food and GrabFood are $20 \%-25 \%$ higher on applications compared to when a customer buys it directly from the vendor. Even though the prices higher, customers were still willing to pay for the services. This finding supports Prabowo and Nugroho (2018) who found that price saving orientation did not affect the post-usage usefulness of Go-Food. Therefore, H4 is rejected. Information on OFD services may be considered as general information and respondents already had knowledge or experience regarding OFD services. In this case, the information listed may no longer be applied when determining the use of service. Images and designs displayed on the OFD application may be considered overly general and familiar for consumers because these images only showed the menu that does not affect consumers in perceiving the services as a useful platform. It supports Dewi et al. (2018) who found that visual appeal did not affect perceived usefulness. Thus, $\mathrm{H} 9$ and $\mathrm{H} 10$ are rejected.

The convenience motivation could be insignificant for the respondents because they were already familiar with OFD services. Pynoo et al. (2011) explained that ease of use is a significant predictor of attitude if consumers have no prior experience. The majority of respondents in this study were generation $\mathrm{Y}$ and $\mathrm{Z}(95.17 \%)$ who were already familiar with the internet, digitalization, and accustomed to high-tech products. Therefore, convenience motivation in using OFD services did not affect their repurchase intention. This finding supports Hussein (2017) who found that ease of use did not affect consumers' purchase intention because consumers already familiar with the 
system and they consider the technology to be relatively easy. Thus, H12 and H13 are rejected. Based on statistical analysis, the mean of attitude is higher than three. This finding indicates that respondents agreed that using OFD services is wise, good, sensible, and rewarding. However, almost $30 \%$ of the respondents stated they will decrease the purchase frequency through OFD services after the COVID-19 pandemic ends. Therefore, a positive attitude towards OFD services did not necessarily encourage consumers repurchase intention. According to Sentosa and Mat (2012), attitude did not influence behavioral intention. Therefore, H16 is rejected.

\section{CONCLUSION AND SUGGESTIONS}

Only eight hypotheses of this study accepted. It was found that: (1) PSO, TSO, and POPE had a significant positive influence on CM; (2) TSO, POPE, and CM had a significant positive influence on PU; and (3) PU had a significant positive influence on AOFDS and RIOFDS. Besides, consumers' attitude towards OFD services was positive and they would repurchase if the service benefits them. Thus, OFD companies must ensure their services are valuable and useful for consumers in every aspect (helping the consumer to shop quickly and effectively). Also, OFD companies must ensure transaction processes in the application is easy and clear, thus the OFD application must be userfriendly to speed up the F\&B purchase process. In OFD services, the aforementioned speed is not just during the online transaction process. It starts from the F\&B order process through the application, payment, and delivery processes.

OFD services companies must ensure the consumer shopping experience is positive (application, duration, driver and retailer quality, communication, etc.). It is also suggested that companies should update their promotions to attract price-sensitive consumers since they tend to choose a site that provides best value. This study is limited by its research model that did not differentiate Go-Food and GrabFood users. Therefore, it is suggested that further study would: (1) conduct differentiate analysis between Go-Food and GrabFood users; (2) add utilitarian motivation in the research model; (3) cultural and technology acceptance differences allow this study to be replicated in other countries; and (4) the technological difference acceptance between generations will allow this study to be tested based on respondent age.

\section{REFERENCES}

Ajzen, I. (1991). The theory of planned behavior. Organizational behavior and human decision processes, $50(2)$.

Audrain-Pontevia, A. F., N'Goala, G., \& Poncin, I. (2013). A good deal online: The Impacts of acquisition and transaction value on E-satisfaction and E-loyalty. Journal of Retailing and Consumer Services, 20(5).

Bhattacherjee, A., Perols, J., \& Sanford, C. (2008). Information technology continuance: A theoretic extension and empirical test. Journal of Computer Information Systems, 49(1), 17-26.

Chiu, C. M., Wang, E. T., Fang, Y. H., \& Huang, H. Y. (2014). Understanding customers' repeat purchase intentions in B2C e-commerce: the roles of utilitarian value, hedonic value, and perceived risk. Information Systems Journal, 24(1), 85-114.

Davis, F. D. (1989). Perceived usefulness, perceived ease of use, and user acceptance of information technology. MIS quarterly.

Dewi, D. S., Sudiarno, A., Saputra, H., \& Dewi, R. S. (2018). The effect of emotional design and online customer review on customer repeat purchase intention in online stores. In Conference Series: Materials Science and Engineering (Vol. 337, No. 1, pp. 1-9). Har, L. C., \& Eze, U. C. (2011). Factors influence consumers' intention to repurchase online in Malaysia. International Journal of Electronic Commerce Studies, 2(2), 157-164.

Hernández-Ortega, B., Jiménez-Martínez, J., \& Martín-DeHoyos, M. J. (2008). Differences between potential, new and experienced e-customers. Internet Research.

Hussein, Z. (2017). Leading to intention: The role of attitude in relation to technology acceptance model in elearning. Procedia Computer Science, 105, 159-164. 
Ingham, J., Cadieux, J., \& Berrada, A. M. (2015). e-Shopping acceptance: A qualitative and meta-analytic review. Information \& Management, 52(1), 44-60.

Limayem, M., Khalifa, M., \& Frini, A. (2000). What makes consumers buy from Internet? A longitudinal study of online shopping. IEEE Transactions on systems, man, and Cybernetics-Part A: Systems and Humans, $30(4), 421-432$.

Loiacono, E. T., Watson, R. T., \& Goodhue, D. L. (2007). WebQual: An instrument for consumer evaluation of web sites. International Journal of Electronic Commerce, 11(3), 51-87.

Lord, R. G., \& Maher, K. J. (1990). Alternative information-processing models and their implications for theory, research, and practice. Academy of management review, 15(1), 9-28.

Quelch, J. A., \& Klein, L. R. (1996). The Internet and international marketing. MIT Sloan Management Review, 37(3).

Prabowo, G. T., \& Nugroho, A. (2019). Factors that influence the attitude and behavioral intention of Indonesian users toward online food delivery service by the Go-Food application. In 12th International Conference on Business and Management Research (ICBMR 2018). Atlantis Press.

Pynoo, B., Devolder, P., Tondeur, J., Van Braak, J., Duyck, W., \& Duyck, P. (2011). Predicting secondary school teachers' acceptance and use of a digital learning environment: A cross-sectional study. Computers in Human behavior, 27(1), 568-575.

Sentosa, I., \& Mat, N. K. N. (2012). Examining a theory of planned behavior (TPB) and technology acceptance model (TAM) in internetpurchasing using structural equation modeling. Researchers World, 3(2 Part 2), 62. 